\title{
DE AFSTAMMING IN DE LANDEN VAN DE MAGHREB
}

\author{
Alfons VAN MENSEL \\ Seminarie Recht van Nieuwe Staten (RUG) \\ Universiteitsstraat 4 \\ 9000 Gent
}

ONDERZOEKSVELD: islam/adoptie/ islamitisch recht

\section{SUMMARY}

\section{PARENTAGE - PROTECTION OF THE LEGITIMATE BIOLOGICAL FAMI- LY - ADOPTION}

The modern codices which govern the personal and family law of islamic people, stay totally absorbed and influenced, by traditional Islamic law.

The main issue in the parentage problem is marriage. Only within marriage, children can legally be procreated. The few adoptations brought about, such as the possibility to adopt, the recognition of natural children in Tunisia, do not change the public image in many ways.

Large attention is focused at the protection of the legitimate biological family-unit. This does not prevent that a very human treatment, in respect of the parentage of children, has been elaborated.

Children are being placed, as much as possible, in the case of a legimitate family through techniques as there exists : recognition by men and women of children with unknown origin, the appointment by children of men and women as their father and mother, ...

Belgian judges, confronted with the application of Islamic law, are showing signs of shortsightedness. 
Too frequently, Islamic law is put aside in favor of international public order.

KEY WORDS : adoption, islam, islamic law

\section{INLEIDING}

1. Sinds de jaren zestig verblijven talrijke Noord-Afrikanen - Marokkanen, Algerijen en Tunesiërs - in ons land. Zij behoren allen tot de Arabische of Berberse cultuur hetgeen hen een aparte plaats geeft in ons westers cultuurpatroon. Bovendien belijdt het overgrote deel van deze mensen de islamitische godsdienst hetgeen het hen al evenmin gemakkelijk maakt in ons midden. Het grootste deel van hen heeft bovendien de oorspronkelijke nationaliteit behouden. Dit is een belangrijke vaststelling voor het opzet van dit opstel. Want dit feit heeft o.m. tot gevolg dat hun personeel statuut(1) - d.i. hun personen- en familierecht beheerst blijft door hun nationaal recht.

2. Alhoewel door al deze factoren in een soort aparte leefwereld gedrongen, zorgt hun aanwezigheid in onze maatschappij voor de nodige raakpunten met de inheemse juridische orde. Zij huwen hier met landgenoten of met Belgen; zij verwekken hier kinderen, binnen en buiten de banden van het huwelijk; zij adopteren, legitimeren en erkennen kinderen; zij scheiden hier zodat de voogdij over hun kinderen moet worden georganiseerd, enz... In eén woord, zij leven hier als volwaardige burgers; als mensen van vlees en bloed.

Hun intrede in onze juridische orde met hun eigen apart personeel statuut zorgt ook voor de nodige pijnpunten voor onze rechters die geconfronteerd worden met een brok islamitisch recht. Bij het nalezen van de rechtspraak die zich in de loop van de jaren vormde, stelt men een zekere onwennigheid vast bij het hanteren van dit "vreemde" recht; ook een aantal onzuiverheden; bijwijlen zelfs onjuistheden; en wat erger is, af en toe een bedekt racisme, ... Al te vaak en al te gemakkelijk wordt het nationale recht van deze personen ter zijde geschoven en werd de juridische problematiek afgehandeld naar Belgisch recht. De laatste tijd worden echter inspanningen gedaan om met meer kennis van zaken de moeilijkheden te behandelen waarin islamitisch recht betrokken is. Nochtans heerst er toch nog steeds heel wat onwetendheid omheen de zo belangrijke materie van de afstamming. Dit opstel wil een bijdrage leveren om enkele onduidelijkheden toch uit de weg te ruimen. Wij hopen met de beperkte kennis die ons eigen is, te slagen in de bescheiden doelstelling. 


\section{Afdeling 1 : Begrip Afstamming (nasab)}

3. Voor het begrip afstamming dient verwezen naar de term "nasab", hetgeen ongeveer zoveel betekent als wettelijke afstamming. Hiermee wordt de juridische band aangeduid die bestaat tussen de vader en de kinderen alsmede het behoren tot de Islam, zoals duidelijk blijkt uit artikel 83 van de Marokkaanse code familiale :

"La filiation légitime est celle par laquelle l'enfant accède à la parenté de son père et suit la religion de ce dernier".

In het islamitisch recht wordt deze band alleen erkend zo het kind verwekt is binnen het huwelijk. Er volgt dan een vermoeden dat het kind door de man van zijn moeder werd verwekt. Voor kinderen die buiten het huwelijk werden verwekt alsmede voor hun erkenning, wettiging of adoptie heeft het islamitisch recht in de regel geen oog.

4. Nochtans brengt het recht zelf een paar correcties aan op deze strenge orthodoxie. Zo laat het islamitisch recht in bepaalde omstandigheden toe dat een man, zelfs wanneer hij stervende is, een kind waarvan de afstamming onbekend is, te erkennen als zijn kind en het aldus op te nemen in zijn nasab. Deze tegemoetkoming berust op het vermoeden dat het kind door de man in een huwelijk werd verwekt. Indien deze operatie echter uitloopt op de vaststelling van een onregelmatige band van afstamming (nl. een overspelige of buitenechtelijke), wordt haar iedere juridische kracht ontzegd : man en kind blijven in de juridische orde voor elkaar volkomen vreemden.

Het onderzoek naar het moederschap is evenwel toegelaten.

Dit kan ook leiden naar het vaderschap. De zijdelingse vaststelling van het vaderschap heeft echter slechts juridische gevolgen zo het vaderschap legitiem is, d.w.z. zo blijkt dat de moeder met de man gehuwd is geweest en tijdens dit huwelijk het kind waarover het gaat, verwekt werd.

5. Zo bekeken blijkt het islamitisch recht m.b.t. de afstamming vrij eenvoudig, zelfs rudimentair hetgeen echter nog niet wil zeggen dat het inhumaan zou zijn. De rechtsgeleerden die het islamitisch recht tot ontwikkeling brachten, spaarden tijd noch moeite om zoveel als mogelijk kinderen binnen het huwelijk te brengen en hun een "legitiem" statuut te bezorgen. Zo ontwierpen zij het leerstuk van de in de moederschoot ingeslapen foetus waardoor zwangerschappen van meerdere jaren mogelijk werden. Dit liet hen toe van kinderen die buiten de limieten werden geboren, in het huwelijk onder te brengen en hen vooralsnog in de nasab van de man te schuiven. De malekitische school die het islamitisch recht in de Maghreblanden een eigenheid meegeeft, laat zwangerschappen toe van zelfs zeven jaar. Kinderen, na de 
ontbinding van het huwelijk binnen deze periode geboren, worden als wettige kinderen van de man beschouwd.

6. Op dit traditionele stramien bouwden de drie Maghreblanden (Algerije, Marokko, Tunesië) hun eigentijds personen- en familierecht verder uit. Hier en daar brachten zij een moderne toets aan; veel bleef echter bij het oude. Toch enkele innovaties t.o.v. het islamitisch recht : nl. het verlaten van de theorie van de "ingeslapen foetus" en het vaststellen van uit medisch-wetenschappelijk oogpunt meer verantwoorde zwangerschapstermijnen. Tunesië waagde zich nog een stap verder en knoopte opnieuw aan bij een pre-islamitische traditie door de adoptieve afstamming van kinderen toe te laten. Het land maakte tevens een opening naar de erkenning van buitenechtelijke, de zgn. natuurlijke kinderen.(3)

\section{Afdeling 2 : De wettige afstamming in de Maghreblanden}

7. De wettige afstamming heeft in de Maghreblanden nog steeds als basis de verwekking van het kind binnen het huwelijk. In die zin stelt artikel 41 van de Algerijnse code de la famille : "L'enfant est affilié à son père par le fait de son mariage, de la possibilité des rapports conjugaux, sauf désaveu de paternité".Het huwelijk en de mogelijkheid van intieme betrekkingen leiden tot het vermoeden van wettig vaderschap dat tot uitdrukking wordt gebracht in het door het Romeins recht geïnspireerd adagium "het kind behoort toe aan de heer van het echtelijk bed" (pater est quem nuptiae demonstrant). Het vermoeden van vaderschap kan voor de rechter bestreden worden met de vordering tot ontkenning van vaderschap.

In een aantal gevallen - en hieruit blijkt opnieuw de humane opstelling tegenover kinderen - gelden ook in Tunesië en Algerije het nietig huwelijk en het door gebreken aangetaste huwelijk als "geldige" basis voor het bepalen van de wettige afstamming.(4) In Marokko vallen kinderen die verwekt werden door een man en een vrouw die ten onrechte meenden een geldig huwelijk te hebben aangegaan, eveneens onder deze regel, voor zover het huwelijk te goeder trouw werd aangegaan. Eigenaardig genoeg doet in dit traditionele land het westerse concept van het putatief huwelijk zijn intrede. In Algerije en Tunesië wordt niet naar de goede trouw gepeild o.g.v. de overweging dat kinderen niet het slachtoffer van een foutief gedrag van hun ouders mogen worden.(5)

8. Om de vraag te beantwoorden welke kinderen geacht worden verwekt te zijn binnen het huwelijk, werd een minimum en een maximum duur van de zwangerschap bepaald : minimum zes maanden na het sluiten van het huwelijk; en maximum én jaar (Tunesië, Marokko) en tien maanden (Algerije) na het beëindigen van het 
huwelijk. Alhoewel sexuele betrekkingen v66r het huwelijk bij wet verboden zijn, betekent dit nog niet dat zij niet plaats grijpen. Vandaar dat van kinderen die na zes maanden huwelijk geboren worden, de wettige afstamming vaststaat t.a.v. de man, en a fortiori t.a.v. de moeder. De kinderen worden geacht verwekt te zijn binnen het huwelijk. Dit geldt ook voor kinderen die geboren worden binnen de tien of twaalf maanden na het beëindigen van het huwelijk.

9. De regeling voor kinderen die vroeger dan zes maanden na het huwelijk geboren worden, trekt een duidelijke scheiding door de landen : in Algerije en Marokko zijn en blijven deze kinderen volgens het recht, onwettige kinderen.(6) Volgens Taverne, M.(7) echter wijkt in Algerije de praktijk af van deze stricte wettelijke regeling.

"Dans la vie musulmane traditionelle il y a en fait peu d'enfants naturels; un mariage peut toujours être conclu très rapidement selon les formes coutumières et permet de régulariser la situation; aucun problème ne se pose pour l'enfant né juste après le mariage, à la condition de se taire sur les conditions moralement condamnables de la conception de cet enfant".

Deze oplossing is echter slechts mogelijk wanneer de datum van het huwelijk niet officiëel is vastgelegd. Wanneer het huwelijk door de ambtenaar van de burgerlijke stand in de registers is overgeschreven, blijkt de door Taverne, $\mathbf{M}$. vooropgestelde oplossing omzeggens onhoudbaar, zoals Wengler, W. stelt : "Auch in Algiers, wo die malekitische Rechtsschule massgebend ist, ist entschieden, dass die Annerkennung unwirksam ist, wenn die voreheliche Erzeugung des Kindes feststeht, insbesondere sich aus dem Standesregister ergibt".(8) Indien echter man en vrouw, als gehuwden samenwoonden zonder officiële huwelijkssluiting mag de rechter in dit geval de datum van het huwelijk in het verleden plaatsen $z \sigma$ dat het kind verwekt is binnen de wettelijk vastgelegde termijnen. Maar alleen zo er geen huwelijk in de registers van de burgerlijke stand werd overgeschreven.

Wellicht onder Franse invloed, wijkt Tunesië ook hier af van het strakke, klassieke patroon door te stellen dat zodanige kinderen wettig zijn, zo de afstamming wordt vastgesteld door het samenwonen, door de bekentenis van de man (zij kan blijken uit de aangifte van de geboorte) en door de getuigenissen van twee of meerdere eerbare personen. Deze mogelijkheid slaat alleen op het vastleggen van de vaderlijke afstamming. De moederlijke afstamming blijkt meestal uit het feit van de bevalling (mater semper certa-regel). 


\section{Afdeling 3 : Buiten het huwelijk verwekte en geboren kinderen}

10. Voor kinderen die buiten het huwelijk verwekt en geboren werden, liggen de kaarten anders. In Algerije en Marokko kunnen zij noch door legitimatie, noch door adoptie als wettige kinderen in de nasab van de man opgenomen worden. In Tunesië is de wettiging of erkenning van dergelijke kinderen evenmin mogelijk (9); zij kunnen evenwel door adoptie als wettige kinderen in de nasab van de man ondergebracht worden.

\section{§1. Ontkenning van vaderschap - Overspel}

11. Het vermoeden dat ieder kind tijdens het huwelijk geboren van de man is, kan zoals eerder gezegd weerlegd worden in een proces tot ontkenning van vaderschap. (10):

a) zo het tijdstip van de conceptie gelegen is in een periode waarin het samenwonen en het onderhouden van sexuele betrekkingen onmogelijk was omwille van de gezondheidstoestand, feitelijke verwijdering (alibi) of geslachtsonrijpheid(11);

b) zo het kind vroeger dan zes maanden na het huwelijk geboren wordt.

Het proces tot ontkenning van vaderschap vindt geen doorgang zo de man op de hoogte was van de zwangerschap; zo de man de vroedvrouw liet halen; zo hij de termijn om het proces in te spannen, liet voorbijgaan. De man kan het kind als het zijne aanvaarden. Dit vloeit meestal impliciet voort uit het feit dat hij het kind aangeeft bij de burgerlijke stand. Naast het voeren van het proces tot ontkenning kan de man zijn vrouw van overspel beschuldigen. Indien hij de li'an-eed hiervoor aanwendt, wordt het uit overspel geboren kind niet in zijn nasab opgenomen. Het wordt een onwettig kind. Het kind kan geen enkele juridische band tot stand brengen, noch met zijn formele noch met zijn natuurlijke vader. Het krijgt evenwel een plaats in de familie van zijn moeder; het blijft echter een onwettig kind.(12)

\section{§ 2. De na het beëindigen van het huwelijk geboren kinderen}

12. Het kind dat in de periode van tien of twaalf maanden na de ontbinding van het huwelijk geboren wordt, - en derhalve verwekt is tijdens het huwelijk - is een wettig kind. De situatie komt anders te liggen zo het kind buiten die periode geboren wordt, d.i. na verloop van tien of twaalf maanden na de ontbinding van het huwelijk. Men kan hieromtrent de vraag stellen of zodanig kind de staat van wettig of onwettig kind 
meekrijgt. Dit is belangrijk want in het ene geval moet een proces tot ontkenning van vaderschap ingespannen worden; in het andere geval niet. Terzake moeten twee gevallen onderzocht worden :

eên : de beëindiging van het huwelijk door het overlijden van de man; en

twee : de beëindiging van het huwelijk door echtscheiding of verstoting.

In het eerste geval menen wij dat - zeker in Algerije - geen vordering tot ontkenning moet ingesteld worden vermits het huwelijk niet meer bestaat; de maximum duur van de zwangerschap duidelijk bepaald werd; de man onmogelijk nog sexuele betrekkingen met de vrouw kon hebben. Het kind dat in deze omstandigheden geboren wordt, is buiten het huwelijk verwekt; het is derhalve onwettig. Het kan alleen aanspraak maken op de afstamming langs moederszijde.(13) In het tweede geval blijft de mogelijkheid open dat er nog sexuele relaties tussen de gewezen echtgenoten hebben plaatsgevonden ook al was er geen huwelijk meer. De relaties grepen derhalve plaats buiten het huwelijk. Het kind is dus buiten het huwelijk verwekt. Het is derhalve onwettig en zal niet moeten ontkend worden. Het is wellicht in deze zin dat art. 43 van de Algerijnse code moet gelezen worden : "L'enfant est affilié à son père s'il nâ̂t dans les six mois suivant la date de la séparation ou du décès".

Wij menen dat deze oplossing ook in de andere landen mag gevolgd worden.

\section{Afdeling 4 : Bewijzen van wettige afstamming}

13. In de traditie van het islamitisch recht kan de wettige afstamming langs vaderszijde ook bewezen worden door het samenwonen, de bekentenis van de vader, getuigenissen van eerbare personen. Deze omstandigheden verzachten de klassieke strengheid. Het openlijk samenwonen en het zich gedragan als echtgenoten alsmede de behandeling van de kinderen als wettige kinderen vormen het bewijs dat de kinderen verwekt zijn in een huwelijk. Sluitend is het bewijs echter niet. Zoals het kan aangevuld worden, kan het ook weerlegd worden door getuigenissen. Hierop baseert de Marokkaanse rechter zich om de onmogelijkheid een kind te erkennen in gevallen waarin de geboorte plaatsvond v66r de termijn die voor de wettigheid van het kind gesteld is, te ontwijken. In dit geval kan de Marokkaanse rechter bepalen dat partijen reeds vo6r de huwelijkssluiting gehuwd waren. Kinderen die minstens zes maanden na de door de rechter bepaalde "datum" van de aanvang van het huwelijksleven zijn geboren, worden als wettig aangemerkt. De rechter baseert zijn vaststellingen op het onafgebroken samenwonen en het samen éen huishouden 
voeren. De rechter zal de verklaring slechts afgeven indien partijen als gehuwden leefden, niet wanneer sprake is van een "vrije relatie". Twaalf getuigen moeten bevestigen dat partijen reeds v66r de geboorte van het kind als man en vrouw samenwoonden.

\section{Afdeling 5 : Erkenning van kinderen van onbekende afstamming}

14. In een aantal omstandigheden wordt de erkenning van kinderen wier afstamming onbekend is toegelaten. De erkenning heeft echter nooit tot gevolg dat de situatie van "natuurlijke" kinderen geregulariseerd wordt. In de toegelaten omstandigheden - een kind wiens afstamming onbekend is - leidt de erkenning steeds tot wettige afstamming t.a.v. de erkenner. Het kind wordt beschouwd als zijnde een wettig kind vanaf zijn geboorte. Dit gevolg wordt door H.F. von Ploetz treffend onder woorden gebracht :

"Das in Art. 92f (Marokko) geregelte Vaterschaftanerkenntnis ist nicht mit dem Anerkenntnis der illegitiemen Vaterschaft des deutschen Rechts zu verwechselen. Es stellt ex tunc die legitime Abstammung zwischen dem Anerkennenden und dem Kind her und setzt voraus, dass es sich um ein Kind unbekannter Abstammung handelt. Über die genaue Definition dieses Begriffes konnte keine Klarheit erlangt werden. Es steht jedoch fest, dass ein I.S. des deutschen Rechts uneheliches Kind nicht gemein ist, das seine Abstammung bekannt ist (diesem Vaterschaft anerkenntnis kommt heute kaum noch praktischer Bedeutung zu)".(14)

\section{§1. Erkenning door man}

15. Zelfs vanop zijn sterfbed mag de man erkennen dat hij de vader is van een kind wiens afstamming onbekend is, voor zover de erkenning niet door rede of gewoonte (man is nooit gehuwd geweest, verschil in leeftijd is te gering, ...)(15) wordt tegengesproken. Indien aan al deze voorwaarden is voldaan, wordt het kind vanaf zijn geboorte in alle opzichten het wettig kind van de erkenner. Tussen het kind en de erkenner ontstaan er erfrechten, huwelijksbeletselen en rechten en plichten m.b.t. het onderhoud die uit de wettige afstamming voortvloeien. Dit gevolg wordt geschraagd door het vermoeden dat het kind door de erkenner verwekt werd binnen een huwelijk. De erkenner dient echter geen huwelijk aan te tonen en evenmin de moeder van het kind aan te wijzen. Dit laatste dient ten stelligste vermeden te worden. De aanwijzing van de moeder zou immers kunnen leiden tot de vaststelling van een "onregelmatige" afstamming : buitenechtelijk kind, overspelig kind, ... De afstamming wordt op deze manier als het ware losgekoppeld van het huwelijk : "Le juge s'interdira donc toute question, toute investigation sur ce point, la naissance étant 
présumée régulière indépendamment de toute critère du mariage. Cela ne signifie pas qu'il n'y a pas eu mariage mais que l'union qui a donné lieu à la naissance, a pu s'accomplir, en raison de la négligence, de l'inadvertence ou de la faute des parents, en dehors des formes prescrites par la loi sinon en violation de ses prohibitions.(16) Om geldig te zijn dient de verklaring van de vader liefst geen elementen te bevatten die de conceptie of de geboorte buiten een huwelijk zouden situeren.

\section{§ 2. Erkenning van ouders}

16. Kinderen van onbekende afstamming, mogen een man en een vrouw als ouders aanduiden. Deze aanwijzing heeft slechts uitwerking in zover man en vrouw hun instemming betuigen met de erkenning. Dit kan slechts zo er huwelijksbanden hebben kunnen bestaan tussen de man en de vrouw en dat uit het huwelijk het initiatiefnemend kind is kunnen geboren worden (leeftijdsverschil). Indien beiden met de erkenning instemmen staan wij voor een volwaardige wettige afstamming van het kind.

\section{§ 3. Erkenning van kinderen door moeder}

17. Ook de moeder mag een kind als het hare erkennen. Om te kunnen overgaan tot de erkenning dient de vrouw feitelijk in staat geweest te zijn om kinderen te dragen. De verwekking dient gelegen in de periode van haar huwelijk. Indien de man die het kind verwekte nog in leven is, heeft de erkenning door de moeder slechts volheid van uitwerking zo de man ze bekrachtigt. Zo hij er niet op ingaat, leidt de erkenning door de moeder slechts tot een onregelmatige afstamming die geen uitwerking heeft t.o.v. de man. Hier geldt derhalve niet het vermoeden van pater est quem nuptiae demonstrant.

18. Kinderen van wie bekend is dat ze buiten het huwelijk verwekt zijn, mogen enkel aanspraak maken op erkenning door hun moeder (door het feit van de geboorte alleen reeds). De rechtsbetrekking tussen de moeder en haar buitenechtelijk verwekte kinderen is gelijk aan die die bestaat tussen haar en haar wettige kinderen. Volgens het recht ontstaan door het feit van de geboorte op zichzelf, tussen een vrouw en haar buitenechtelijke verwekte kinderen alle gewone betrekkingen van bloedverwantschap, erfrecht, wederzijdse onderhoudsplicht, huwelijksbeletselen, ... 


\section{Afdeling 6 : Adoptie-verbod}

19. In de pre-Islamtijd was adoptie (tabanni) een ruim verspreide instelling, waardoor een juridische band ontstond tussen de adoptant en de geadopteerde die diens naam droeg alsmede erfenisrechten verkreeg. De adoptieve afstamming riep ook huwelijksbeletselen in het leven. Vooral dit laatste aspect leidde tot de afschaffing van de instelling. Mohammed had namelijk zelf een aangenomen zoon Zaïd die gehuwd was met een vrouw waarop de profeet zijn zinnen had gezet. Vermits de adoptieve afstamming huwelijksbeletselen in het leven riep, kon de profeet zijn schoondochter - zelfs na ontbinding van het huwelijk met zijn aangenomen zoon - niet huwen. Op verzoek van Mohammed verstootte Zaïd zijn vrouw waarop Mohammed met haar trouwde tot ontstentenis van de goegemeente. Vandaar de gevleugelde tussenkomst van de engel Gabriël die een aangepaste boodschap bracht :

"Wie zijn afstamming afleidt van iemand die niet werkelijk zijn vader is, dien zullen Allah en de engelen benevens alle mensen vervloeken". De afschaffing van de adoptie had echter niet tot gevolg dat de instelling zomaar in de vergetelheid geraakte. De instelling bleef feitelijk nawerken, echter ontdaan van haar juridische gevolgen. In Algerije en Marokko ligt het moderne recht derhalve helemaal in de lijn van het klassieke islamitisch recht waar de juridische opname in de familie van een "vreemd" kind verboden was, doch waar tegen de feitelijke opname in de familie als erfgenaam (kafala) geen bezwaar werd gemaakt. In het kader van de instelling van de feitelijke adoptie neemt een persoon vrijwillig de verbintenis op zich de lasten van onderhoud, opvoeding en bescherming van verlaten, behoeftige minderjarige kinderen te dragen. De toelating ervoor wordt verleend voor een rechter of een notaris met de toestemming van het kind zo hij nog ouders heeft. De feitelijke adoptant moet moslim zijn. Bovendien moet hij in staat zijn in het onderhoud en de bescherming van het kind te voorzien. Hij wordt voogd van het kind met alle gevolgen van dien. Hij mag zijn pupil met legaten en schenkingen begiftigen. Limiet : 1/3 van zijn vermogen. Van deze regel mag afgeweken worden met instemming van de andere erfgenamen. Het kind kan ook in zijn oorspronkelijke familie terugkeren op vraag van zijn ouders of van éen ervan. De beslissing ligt bij het kind zo het tot de jaren van verstand is gekomen. Het laatste woord ligt echter bij de rechter die beslist in functie van de belangen van het kind.

20. Tunesië verliet het klassieke pad en liet de juridische adoptie opnieuw toe. Iedere gehuwde meerderjarige Tunesiër of vreemdeling (17) mag, mits instemming van zijn echtgenote, een kind adopteren. De adoptant dient van goed gedrag en zeden te zijn, gezond naar geest en lichaam en in staat zijn om de behoeften van de geadopteerde te kunnen voorzien. Daarenboven dient hij vijftien jaar ouder te zijn dan de geadopteerde. Dit geldt niet zo de geadopteerde het kind is van de echtgenote van de adoptant. In deze laatste afwijking ligt én van de redenen van de invoering van de 
adoptie-instelling in Tunesië. Zij biedt de mogelijkheid om de "natuurlijke afstamming" te regulariseren.

De geadopteerde dient minderjarig te zijn. Zijn nationaliteit doet er niet toe. De adoptie krijgt haar beslag voor de rechter die bij vonnis de adoptie-akte vaststelt. Het vonnis dat uitgesproken wordt in tegenwoordigheid van de adoptant, van zijn echtgenote en in die van de ouders van de geadopteerde, is definitief. Een uittreksel van het vonnis wordt overgemaakt aan de bevoegde ambtenaar van de burgerlijke stand die het in de marge van de geboorteakte van de geadopteerde overschrijft. De geadopteerde is drager van dezelfde rechten en plichten als een wettig kind. Hij draagt voortaan de naam en de nationaliteit van de geadopteerde. De adoptant heeft t.o.v. de geadopteerde dezelfde rechten en plichten die de wet op de ouders legt. Verder dan die relatie gaan de verplichtingen niet, zoals Taverne, M.(18) stelt "l'adoption ne recouvre pas exactement la notion de filiation légitime. En effet, les effets sont limités à ceux décrits ci-dessus et il n'y aura dès lors pas d'empêchements au mariage ni d'obligation alimentaire au-delà des parents adoptifs. De plus, aucune disposition du code de statut personnel ne prévoit une quelconque part de succession en faveur de l'adopté". De rechtbank van eerste aanleg mag, op verzoek van de procureur van de republiek, de hoede over de geadopteerde ontnemen aan de adoptant die schromelijk aan zijn verplichtingen te kort zou komen. De rechter mag in deze omstandigheid de hoede in het belang van het kind aan een andere persoon toevertrouwen.

\section{Afdeling 7 : Toepassing van islamitisch recht in België}

\section{§1. Erkenningsperikelen}

21. De toepassing van het islamitisch recht in België verloopt niet rimpelloos, zoals blijkt uit een overzicht van rechtspraak.(19) De auteurs Erauw, J. en De Foer, L. geven volgende samenvatting :

"Zo kon in twee gevallen een Belgische vrouw haar eigen in overspel verwekt natuurlijk kind onder Belgisch recht, door adoptie wettigen, omdat het een wettig kind van haar man was geworden. Eigenlijk had de man eenvoudig het kind erkend in een akte van religieuse huwelijkssluiting volgens Marokkaans recht. In termen van de man zijn Marokkaans personeel statuut bracht die erkenning het kind de staat van wettig kind tegenover de beide ouders. Voor wat de moeder betreft strookte dat niet met de Belgische benadering. De wettige afstamming tegenover én ouder werd dus aangenomen (Jeugdrecht. Brussel, 15 juni 1981, J.T., 1981, 760, noot D.S. - hier was het muzelmans huwelijk in België gesloten, nadat voor de ambtenaar (...) de 
wettiging t.a.v. de man in Marokko was bekomen, in de huwelijksakte)."

De oplossing die hier wordt weergegeven, vindt geen basis in het islamitisch recht in het algemeen en het Marokkaanse recht in het bijzonder. De aangehaalde gevallen hebben als voorwerp de wettiging door adoptie van overspelige kinderen. Het staat buiten elke betwisting dat duidelijk buiten het huwelijk verwekte kinderen nooit het voorwerp kunnen uitmaken van erkenning in het Marokkaanse recht. Het gaat hier bovendien om overspelige kinderen die geboren en verwekt werden in een huwelijk waaraan de verwekker juridisch niet deelnam. Het is ondenkbaar dat zodanige kinderen in het islamitisch recht erkend worden. Voor het Marokkaanse recht blijven zodanige kinderen steeds en altijd onwettige kinderen die alleén afstammingsbanden hebben met hun moeder. De kwalificatie "overspelige kinderen" wijst er immers op dat hun juridische vader met succes een actio tot ontkenning van vaderschap instelde. De buitenechtelijke afstamming van zodanige kinderen staat lijnrecht vast. Hieraan kan in het islamitisch recht niet zo worden gesleuteld dat hun overspelig karakater weggezuiverd wordt en zij alsdan nog langs een omweg "wettige kinderen" kunnen worden.

Voor een tweede illustratie van de gebrekkige kennis, neem ik elementen uit een commentaar van J. Erauw op een vonnis van de Rb. Antwerpen, 2 november 1983.(20) Het besproken geval heeft tot voorwerp de betwisting door een vrouw van de erkenning van haar kinderen door een Algerijnse man, nadat de vrouw na vijftien jaar samenwonen met hem dag gebroken. De stelling van de vrouw was gebaseerd op het klassieke islamitisch recht volgens hetwelk het niet toegelaten is "natuurlijke kinderen" te erkennen. Wellicht werd bedoeld dat de man bekende dat de kinderen verwekt waren tijdens het samenwonen, dat het samenwonen in Marokko als bewijs kan gelden van het huwelijk, dat derhalve de kinderen verwekt waren binnen het huwelijk en als zodanig wettige kinderen waren. Eén verduidelijking toch : de bekentenis van de man wordt aanvaard wegens het niet waterdicht functioneren van de burgerlijke stand in Marokko. Dit kan men bezwaarlijk in België laten gelden. Derhalve heeft de bekentenis van de vader in België niet die verdragende juridische gevolgen. De kinderen blijven natuurlijke kinderen die door de Algerijnse vader onmogelijk kunnen worden erkend.

In zijn commentaar maakt Erauw, J. van de gelegenheid gebruik om ook de bepalingen van de Algerijnse Code de la famille van 1984, inzake afstamming te bespreken. Wanneer de auteur stelt "De afstamming (art. 40) volgt slechts uit het huwelijk maar kan ook door bewijsvoering met getuigen in een gerechtelijke vaststelling worden afgedwongen. Er moet echter altijd op een wettige afstamming worden gesteund en die veronderstelt een huwelijk. Maar ook het huwelijk kan door de rechter - achteraf - geldig verklaard worden : art. 22", gaat hij aan enkele fundamentele gegevens voorbij. 
Een wettige afstamming veronderstelt een verwekking binnen een huwelijk. Wanneer er sprake is van het vaststellen van een wettige afstamming door getuigen dan wordt bedoeld dat door getuigen aangetoond wordt dat het kind verwekt is binnen een huwelijk. Het huwelijk wordt normaliter bewezen door een uittreksel uit de burgerlijke stand. Indien het huwelijk niet werd geregistreerd kan de rechter zodanige huwelijken toch geldig verklaren, zo alle constitutieve elementen van het huwelijk verenigd zijn (toestemming van trouwers, aanwezigheid van getuigen, bruidschat, ...). Maar ik herneem wat ik daarnet zei : in België functioneert de burgerlijke stand perfect. Derhalve geldt te lande niet wat in Algerije kan gelden : nl. het samenwonen als huwelijk laten valideren.

\section{§2. Adoptie-perikelen}

22. En nu de adoptie-perikelen of hoe kijken Belgische rechters aan tegen adoptie van en door Algerijnen en Marokkanen? De situatie onder de oude wetgeving kan alleen maar bekeken worden. Sindsdien werd de wet gewijzigd en de mogelijkheden om vreemde kinderen te adopteren werden verruimd. In het oude stelsel stond artikel $344 \S 1 \mathrm{BW}$. centraal in de adoptie-problematiek :

"Adoptie is mogelijk onder vreemdelingen, onder vreemdelingen en Belgen, in de vormen van het Belgisch recht, zo, ieder van de partijen aan de voorwaarden voldoen opgelegd in haar personeel statuut".

Overeenkomstig art. 3, lid $3 \mathrm{BW}$. moet derhalve teruggegrepen naar de nationale wet. Slechts uitzonderlijk stelt De Foer, L. mag de aanknoping voor het personeel statuut elders gebeuren.(21) Zoals uit de hierboven gedane uiteenzetting blijkt, verbiedt het Algerijnse en Marokkaanse recht de adoptie alsmede de legitimatie door adoptie. Dit houdt in dat Algerijnen en Marokkanen in België niet mogen adopteren, noch geadopteerd mogen worden. Bepaalde rechters passen deze regel correct toe; andere kunnen het verbod moeilijk verwerken en overtreden bewust art. $344 \S 1 \mathrm{BW}$. door t.o.v. een Marokkaan die een Belgisch kind wil wettigen door adoptie, Belgisch recht toe te passen.(22) De rechter meende een conflict te ontwaren tussen de door art. 344 § 1BW. aangewezen recht van het vaderland, waarmee de kandidaat adoptant geen enkele binding meer had en de wet van de woonplaats waar hij zich volledig geintegreerd had. Het conflict diende in het belang van het kind opgelost te worden door de aanknoping bij de wet van de woonplaats. Andere rechters schuiven op een bijna brutale wijze het vreemde recht van de tafel met inroeping van de internationale privaatrechtelijke openbare orde. Het Hof van Beroep te Luik (23) riep het belang van het kind in om deze stap te wagen. Op 9 januari 1979 herhaalde de rechtbank van Luik (24) deze juridische miskleum en riep in hoogdravende bewoordingen in dat adoptie en legitimatie door adoptie zo intiem verbonden zijn met de zorg voor de bescherming van de jeugd, met de organisatie van de afstamming (...) en derhalve 
met de "principes considérées comme essentiels à l'ordre moral, politique et éconopique" van ons land. Deze bewuste aanslag op het personeel statuut van vreemdelingen werd in het algemeen scherp afgekeurd in de rechtsleer. Er werd gesteld dat het begrip van de internationale openbare orde te ruim gehanteerd werd. "Bovendien", schrijft Lenaerts, K., "miskenden zij de uitdrukkelijkheid van de wetgever om vreemde wetgevingen betreffende het persoonlijk statuut van adoptanten en geadopteerden geëerbiedigd te zien, zelfs wanneer hun inhoud tegengesteld was aan de Belgische adoptiewetgeving".(25)

23. De rechtgeaarde kritiek schrikte de rechters echter niet definitief af.(26) Zij werden echter subtieler in de opvang van de feiten. Zo volgde de Jeugdrechtbank te Brussel in een vonnis van 23 juli 1980 (27) de argumentatie van het Hof van Beroep te Luik, om de wettiging door adoptie van een Marokkaans kind door Belgen te homologeren, maar het liet niet na te benadrukken dat de aanwending van de internationale openbare orde des te meer verantwoord is naarmate de situatie nauwer met de Belgische rechtssfeer is verbonden. Het kind was volledig in de Belgische samenleving geïntegreerd; het had geen enkele binding met zijn vaderland en het had het contact verloren met de persoon, waaraan het zijn nationaliteit ontleende. Zijn Marokkaanse natuurlijke moeder was nl. uit de ouderlijke macht ontzet. Bij nader toezien wordt de internationale openbare orde hier eigenlijk gebruikt om naast de wettelijke aanknoping bij de lex patriae een subsidiaire verwijzingsregel te construeren. Dat opzet blijkt nog duidelijker uit een vonnis van de Jeugdrechtbank te Brussel dat over de Marokkaanse wet heenstapte op grond van de overweging dat de toepassing van de vreemde wet strijdig is met de internationale openbare orde, telkens wanneer de situatie zo nauw met de Belgische rechtsorde verbonden is, dat, die over de normaal toepasselijke vreemde wet de bovenhand haalt. (28) Het Hof van Beroep verzachtte weliswaar deze uitspraak door het uitzonderlijk karakter van de internationale openbare orde te benadrukken. Het Hof kwam niettemin tot dezelfde conclusie. Het is volgens het Hof essentieel dat een verlaten kind juridisch kan geïntegreerd worden in het gezin dat het kind definitief heeft opgenomen. Een wetgeving zoals de Marokkaanse die geen enkele mogelijkheid daarvoor openstelt, leidt in het concreet geval tot een onaanvaardbaar resultaat.(29)

\section{§ 3. Aanpassing adoptierecht}

24. In de toepassing van art. $344 \S 1 \mathrm{BW}$. trad een ongenoegen op de voorgrond dat zich veruitwendigde in een allesbehalve gefundeerde rechtspraak. Vandaar dat de noodzaak werd aangevoeld om de adoptie-regeling wat op te frissen. Artikel 344 $\mathrm{BW}$. werd in een nieuw kleed gestoken en de regeling werd verder uitgewerkt in de artikelen 344bis, 344ter en 344 quater BW. 
In de oude regeling werd de vraag naar de toelaatbaarheid afhankelijk gesteld van het bestaan van de adoptieve afstamming als instelling, zowel in het personele recht van de adoptant als in dat van de geadopteerde. In de nieuwe regeling wordt ze in functie van een aantal criteria bepaald die verschillend zijn naargelang de geadopteerde de leeftijd van 15 jaar bereikt heeft of niet op het ogenblik waarop de akte van adoptie wordt verleden of op het ogenblik waarop het verzoekschrift tot het bekomen van een adoptie bij vonnis wordt ingeleid.

25. Indien de geadopteerde (Algerijn, Marokkaan, Belg) 15 jaar of ouder is, wordt de toelaatbaarheid van de adoptieve afstamming beoordeeld zoals voorheen, nl. door de toepassing van de personele wet van elk van de partijen d.z. adoptant(en) en geadopteerde.

26. Indien de geadopteerde minder dan 15 jaar is dienen verschillende omstandigheden te worden bekeken.

Eerste omstandigheid : er is slechts én adoptant. Dan wordt gekeken naar de personele wet van de adoptant. Indien de personele wet van de adoptant de adoptieve afstamming kent, is de adoptieve afstamming in ons land toegelaten. Vb. Belg of Tunesier adopteert Marokkaanse jongen of meisje. Indien de personele wet van de adoptant de adoptieve afstamming niet kent, is de gewone adoptie niettemin in ons land toegelaten voor zover éen : de geadopteerde in België geboren is of er sedert minstens twee jaar verblijft, en voorzover twee : de adoptant kan aantonen dat hij sedert tenminste vijf jaar gewoonlijk, regelmatig en ononderbroken in België verblijft.

Vb. : Marokaan adopteert een kind dat hij verwekt heeft bij een Belgische vrouw. Het feit dat de personele wet van de geadopteerde de adoptieve afstamming als instelling kent is derhalve volkomen irrelevant geworden.

Tweede omstandigheid : er zijn twee adoptanten. Eerste mogelijkheid : beide adoptanten hebben dezelfde nationaliteit. In dit geval wordt de toelaatbaarheid van de adoptie in België beoordeeld volgens hun personele wet.

Tweede mogelijkheid : de adoptanten hebben een verschillende nationaliteit. In deze veronderstelling wordt de toelaatbaarheid van de adoptie beoordeeld volgens de Belgische wet voorzover de adoptieve afstamming als instelling in hun personeel statuut gekend is.

Indien het personeel statuut van slechts én van de adoptanten de adoptieve afstamming kent dan is alleen de gewone adoptie toegelaten bij toepassing van de Belgische wet voor zover de boven aangehaalde voorwaarden van verblijf in België in hoofde 
van adoptanten als geadopteerde vervuld zijn.

Indien een Belgische vrouw en een Marokkaanse man een Marokkaans kind willen adopteren, kan dat best. Enkel alleen gaat het om de gewone adoptie. Bovendien dient de Marokkaanse man sedert minstens vijf jaar gewoonlijk, regelmatig en ononderbroken in België te verblijven. Het Marokkaans kind dient in België te zijn geboren of sedert minstens twee jaar in België te verblijven.

27. In bepaalde gevallen leidt de adoptie-procedure slechts tot de gewone adoptie die staat tegenover de volle adoptie. Waar ligt het verschil ? Door de gewone adoptie verkrijgt de geadopteerde het statuut van kind van de adoptant. Hij blijft echter banden houden met zijn oorspronkelijke familie. Bovendien treedt hij niet toe tot de familie van de adoptant. Er ontstaat slechts een juridische band tussen geadopteerde en de adoptant(en).

Daarentegen leidt de volle adoptie de geadopteerde binnen als volwaardig lid in de familie van de adoptant(en). De banden met zijn oorspronkelijke familie worden verbroken.

28. Vermits beide vormen van adoptie juridische banden teweegbrengen tussen geadopteerde en adoptant(en), zijn zij voor Algerije en Marokko onaanvaardbaar daar beide landen vooralsnog de adoptieve afstamming niet kennen. Het optreden van onderdanen van beide landen als geadopteerde of als adoptant kan dan ook aanleiding geven tot narigheid voor geadopteerden wanneer zij samen met hun adoptie-ouders naar hun land van herkomst terugkeren. Daar vervallen zij tot de mindere status van buitenechtelijke kinderen, zo zij de natuurlijke kinderen zijn van de adoptanten; of tot het statuut van wettige kinderen t.o.v. personen die verschillen van de adoptanten. Deze moeilijkheden zijn door de nieuwe regeling helemaal niet opgelost. Het kon ook niet anders.

\section{Besluit}

29. Als uitleiding dit : de afstamming in de landen van de Maghreb wordt beheerst door moderne codices die echter doordrenkt zijn van het traditionele islamitisch recht. De enkele retouches, de enkele openingen naar westers recht kunnen dit algemeen beeld nauwelijks verstoren. Centraal in de afstammingsproblematiek staat het huwelijk. Enkel het huwelijk laat sexuele betrekkingen toe; enkel binnen het huwelijk worden wettige kinderen verwekt. De enkele correcties die werden aangebracht - mogelijkheid tot adoptie, opening naar de mogelijkheid om over te gaan tot erkenning van natuurlijke kinderen in Tunesië - veranderen weinig aan het traditioneel islamitisch personen- en familierecht. 
Net zoals in de tijd van de profeet Mohammed draait het afstammingsrecht omheen de meerwaarde van de gehuwde man, de spilfiguur van het maatschappelijk leven : de verwekker van wettige kinderen, ... Vandaar de zorg die wordt besteed aan de bescherming van de wettige biologische familie, ten einde nog meer de positie van de gehuwde man te verheffen. De islamitische wereld is een mannenwereld. Wij kunnen er niet naast kijken, of het ons stoort of niet : het feit is daar.

30. De bescherming van de wettige biologische familie loopt uit op een zeer humane behandeling van de afstamming van de kinderen. Wegens de zeer slechte situatie van buitenechtelijk verwekte kinderen worden kinderen zoveel als mogelijk in de veilige schoot van de wettige familie opgenomen. Eertijds gingen de juristen zelfs zo ver dat zij zwangerschap van zeven jaar aannamen. Deze humane zorg mag ons echter niet zo eenzijdig verblinden dat wij hierin ook niet een bevestiging zouden zien van de meerwaardige positie van de gehuwde man. Want wat tast er zijn eer meer aan dan het moeten toegeven dat binnen zijn huwelijk buitenechtelijke kinderen werden verwekt. Maar toch ...

Even staan wij versteld van de negatieve instelling voor de juridische uitbreidingsmogelijkheden van de familie d.m.v. de adoptieve afstamming. Deze negatieve ingesteldheid is alleen historisch te verklaren aan de hand van het onortodox sexuele gedrag van de profeet Mohammed waaraan de goegemeente aanstoot nam. Om huwelijksbeletselen op te heffen werd meteen de poort voor de juridische uitbreiding van de wettige familie gesloten. Algerije en Marokko stellen zich terzake zeer traditioneel op en laten zich niet leiden zoals Tunesië - door modernere opvattingen. De godsdienstige krachten versperden de weg voor elke nieuwlichterij. Zo men al eens een moderne toets waarneemt in het familierecht, dan blijkt het bij nader toezicht eerder om terminologische vernieuwing te gaan : oude wijn in nieuwe zakken?

31. Belgische rechters die geconfronteerd worden met de toepassing van islamitisch recht geven vaak blijken van kortzichtigheid. Teveel islamitisch recht wordt opzij geschoven door om de haverklap de notie van de internationale orde te hanteren; erger wordt het wanneer islamitische rechtsnoties ontdaan worden van hun reële inhoud (vb. moutâ) en ingevuld worden door Belgisch recht (vb. periodieke betalingen van alimentatie). Ofwel past men inzake van het personeel statuut vreemd recht toe in zijn totaliteit; ofwel schaft men de regel overeenkomstig dewelke inzake het personeel statuut de nationaliteit van betrokkene het toe te passen recht bepaalt en creëert men naar Romeins voorbeeld een ius gentium dat op vreemdelingen toepasselijk is van zodra ze onze leefwereld binnentreden. 


\section{NOTEN}

(1). Er staat wel degelijk "personeel" statuut. Dit is de correcte term. Hij betekent "behorende tot, betrekking hebbende op een bepaalde persoon" (Van Dale).

(2). Zie ook ROMMEL, G., Le statut personnel marocain, T.v.V., 1980, 218.

(3). In Marokko kwam de vernieuwing tot stand o.g.v. een reeks afzonderlijke wetten: het huwelijk wordt geregeld in het dahir nr. 1.57 .343 van 22 november 1957 (staatsblad 23 mei 1958); de afstamming (dahir nr. 1.57 .379 van 18 december 1957, staatsblad 25 juli 1958); de bekwaamheid (dahir nr. 1.58 .019 van 25 januari 1958, staatsblad van 28 december 1958); het testament (dahir nr. 1.58.073 van 20 februari 1958, staatsblad 20 februari 1959). Het geheel vormt de Moudawwana of de Code de statut personnel et des successions.

Tunesië vaardigde op 13 augustus 1956 een code de la famille (Magalla) uit (Décret du 13 aôut 1956 portant Code de Statut personnel. Tunesische Staatsblad 28 december 1956) - Inwerkingtreding : 1 januari 1957.

Algerije deed er wat langzamer over. Op 9 juni 1984 werd ook hier een code de la famille ingevoerd (Loi n 84-11 du 9 juin 1984 portant code de la famille).

(4). De regel waarin een weerlegbaar vermoeden tot uiting wordt gebracht, werd in de pre-islamtijd zelfs ook dan toegepast wanneer het duidelijk was dat het geboren kind niet door de echtgenoot verwekt was, bv. zo een verstoten zwangere vrouw een nieuw huwelijk aanging en daarna beviel. Ook in dat geval gold haar nieuwe echtgenoot als de wettige vader van het kind, al stond het vast dat niet hij, maar de vroegere echtgenoot het had verwekt. Door de invoering van de idda-periode (wachtperiode) werden dergelijke kroostverwarringen grotendeels voorkomen.

(5) Enkele voorbeelden van nietige en gebrekkige huwelijken :

- het huwelijkskontrakt bevat een clausule die strijdig is met het voorwerp van het kontrakt; $v b$. het niet betalen van een bruidschat;

- één van de echtgenoten zwoer de islam af;

- de vrouw behoort tot een categorie van vrouwen waarmee niet mag worden gehuwd omwille van bloed-, aan- of zoogverwantschap. Toch dit ter verduidelijking. Het zogen door een min brengt ook huwelijksbeletselen teweeg. De melkwordt met bloed gelijkgesteld. Melkverwantschap gelijkt aan bloedverwantschap.

(6) De kinderen zijn immers verwekt buiten het huwelijk. Nu zijn geslachtsbetrekkingen buiten het huwelijk niet geoorloofd. Zodanige kinderen zijn en blijven onwettig. Zij kunnen en mogen in geen huwelijk geschoven worden door latere wettiging. Nochtans valt het voor dat de man het kind als het zijne aangeeft. Vaak volgt hierop geen reactie. Nochtans is het geen definitieve toestand. Meermaals - altijd dat geld - wordt de wettigheid van zodanige kinderen betwist n.a.v. erfenisperikelen (Pearl, D., A Textbook for Moslim Law, 78-80). 
(7) TAVERNE, M., Le droit familial maghrébin, Bruxelles, Larcier, 1981, 87.

(8) WENGLER, W., Die Anerkennung des Kindes im Islamrecht und ihre Bedeutung für das deutsche Personenstandsrecht, Das Standesambt, 1964, nr. 6, 151.

(9) Cas. 31 december 1963, R.T.D., 1963, 49. "Le code du statut personnel ne reconnaît pas comme légitime l'enfant né de relations hors mariage ... L'aveu de sa paternité par un homme qui reconnaît n'être pas dans les liens du mariage avec la mère de l'enfant, ne peut faire foi car il tend à établir un fait contraire aux bonnes moeurs".

(10) BENATTAR, M.R., La Filiation dans le code de statut personnel tunisien, R.T.D., 1963-1965, 25-26.

(11) De rechtbank van eerste aanleg te Brussel (18 november 1981, Rev. Trim. Dr. Fam., 1982, 300) beslistte dat de feitelijke scheiding van meer dan twaalf maanden het vermoeden van vaderschap ophief zodat voor kinderen die in deze periode werden geboren, geen proces tot ontkenning van vaderschap moest gevoerd worden. In het licht van artikel 90 van de Marokkaanse code de la famille, blijkt dit een foute beslissing te zijn : "Seul un jugement peut écarter la filiation paternelle d'un enfant ou décider que la grossesse d'une femme n'est pas l'oeuvre de son mari".

(12) De li'ân-eed is een sacramentele eed aangewend door de man om zijn vrouw van overspel te betichten zonder dat hij ervan het bewijs behoeft te leveren.

(13) Nochtans dient het kind de uitdrukkelijke toestemming van zijn grootvader langs moederszijde of van de oudste van de familie om de familienaam van zijn moeder te mogen dragen. (Zie : CHAFI, M., Le Nom de famille au Maroc, R.J.P., 1989, nr. 1, 11).

(14) BERGMANN \& FERIT, Internationales Ehe- und Kindschaftsrecht, 16.

(15) In het algemeen neemt men een leeftijdsverschil aan van 12 jaar tussen de vader en het kind. Het verschil wordt bekomen door de minimumduur van de zwangerschap (6 maanden) bij de minimumleeftijd van de puberteit ( 12 jaar) te tellen.

(16) BENATTAR, M.R., La filiation dans le code de statut personnel tunisien, R.T.D., 1963-1965, 26.

(17) De vreemdeling die een Tunesisch kind adopteert, dient tot de islam te behoren (Tribunal de justice cantonale de Tunis, 26 december 1974, R.T.D., 1975, II, 117).

(18) o.c., nr. 239. Zie ook PRUVOST, L., Le Statut juridique du mineur en Tunesie, R.T.D., 1975, 295.

(19) De afstamming, de gevolgen van de afstamming en de minderjarigen. Overzicht van Rechtspraak (1965-1984). Internationaal Privaatrecht, T.P.R., 1984, nr. 4, nr. 101.

(20) T.v.V., 1986, 114-121. 
(21) De Adoptie en de Wettiging door Adoptie, T.P.R., 1984, nr. 4, 141.

(22) Jeugdrb. Gent, 7 november 1969. Rev. Trim. Dr. Fam., 1970, 58. Jeugdrb. Brussel, 26 maart 1970, Rev. Trim. Dr. Fam., 1970, 74-76. Jeugdrb. Antwerpen, 4 oktober 1971, R.W., 1971-1972, 1319. Brussel, 24 februari 1972, R.W., 1973-1974, 1609. Liège, 30 mei 1983, Rev. Trim. Dr. Fam., 1984, 55.

(23) Liège, 17 juni 1974, J. de Liège, 1974-1975, 14.

(24) Liège, 9 januari 1979, J.T., 1979, 235-236. Rev. Trim. Dr. Fam., 1979, 397 met noot van Dalcq, J., Rev. Not. B., 1979, 628.

(25) Jeugdrb. Turnhout, 20 februari 1981, R.W., 1980-1981, 2740 met noot van K. Lenaerts. Jeugdrb. Brussel, 15 april 1985, T.v.V., 1986, nr. 1, volgens Erauw, J. (Vragen rond de integratie van vreemde patronen van familierecht in het Belgisch rechtsleven, in Buitenlandse minderheden in Vlaanderen-België, Antwerpen-Amsterdam, Nederlandsche Boekhandel, 1984, 188) dienden de rechters op casuïstische basis afwijkingen te zoeken : vooral in adoptiezaken. Volgens de auteur gebeurt dit soms met technische trucs.

(26) DE FOER, L., Adoptie, ..., T.P.R., 1984, nr. 4, 1421.

(27) Adm. Jur. Inf., 1981, nr. 14, 17.

(28) Jeugdrb. Brussel, 12 mei 1982, Rev. Trim. Dr. Fam., 1983, 198.

(29) Brussel, 9 november 1982, Rev. Trim. Dr. Fam., 1983, 200. 


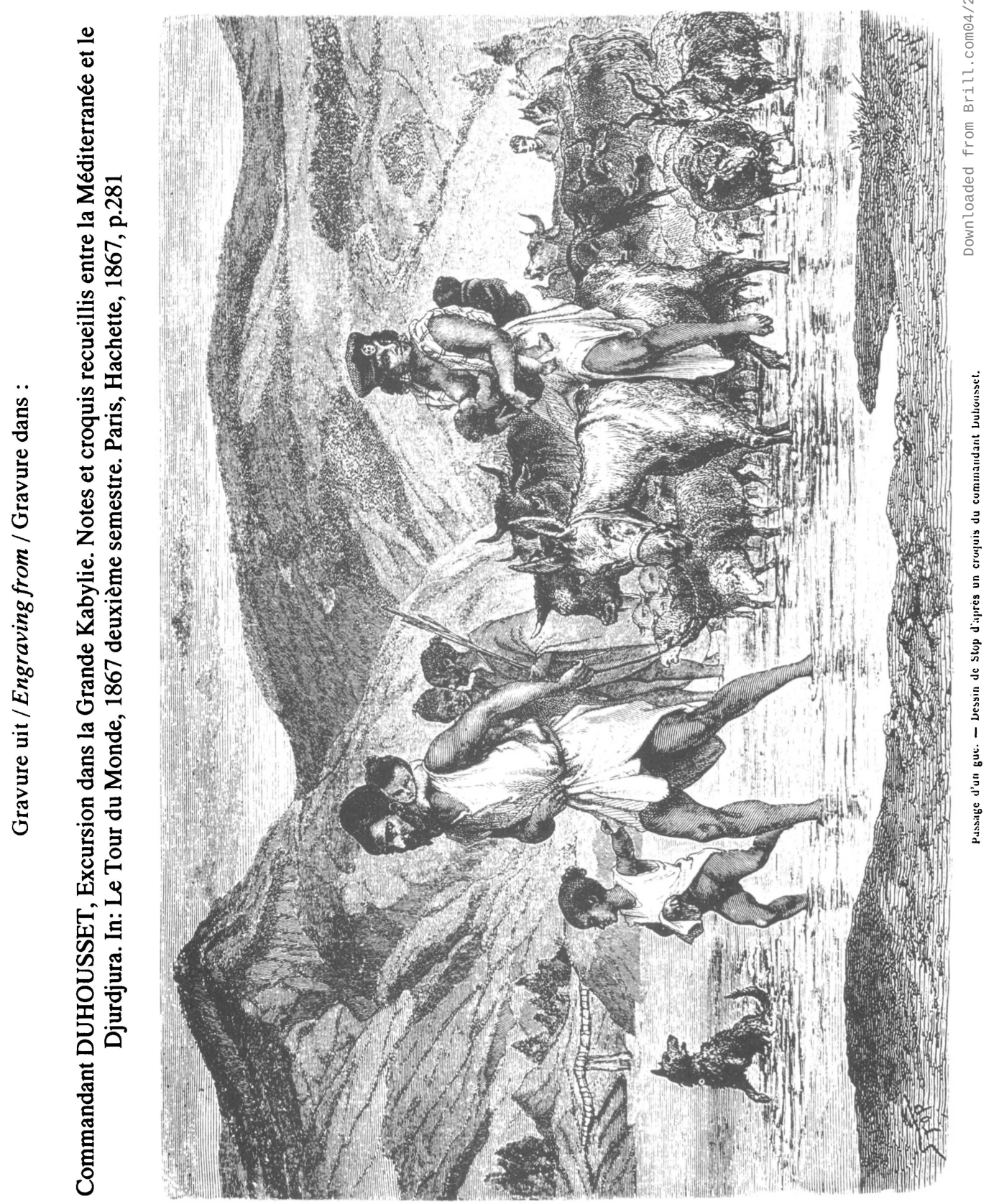

